\title{
Contractor's Perception on Factors Causing Cost Overrun in Construction Works of Pakistan
}

\author{
Abdul Qadir Memon ${ }^{1}$, Aftab Hameed Memon ${ }^{1 *}$, Mohsin Ali Soomro ${ }^{1}$ \\ ${ }^{1}$ Department of Civil Engineering, \\ Quaid-e-Awam University of Engineering, Science and Technology, Nawabshah, PAKISTAN \\ *Corresponding Author
}

DOI: https://doi.org/10.30880/ijscet.2020.11.03.009

Received 30 January 2020; Accepted 29 June 2020; Available online 30 June 2020

\begin{abstract}
This paper assessed the occurrence and severity level of various factors causing time and cost overrun in construction projects of Pakistan. Investigation was carried out through questionnaire form prepared based on 55 common factors identified from literature. Survey was done amongst the representatives of the contractors involved in handling construction activities in Pakistan. A total of 46 responses gathered against 100 distributed forms were analysed statistically. The results obtained from the analyses based on Average Index values revealed that delay in obtaining permits from the governmental agencies, financial difficulties are common issue faced in construction works of Pakistan. The study also revealed that high cost of machinery \& its maintenance, inadequate planning \& scheduling and slow information flow between parties have significant effect on time overrun cost while critical factors affecting cost overrun are high cost of machinery \& its maintenance, unsuitable construction methods and lack of experience of contractors in affecting project cost. The findings of this study will be helpful for the practitioner in planning for achieving timely completion of the projects and also within the estimated cost.
\end{abstract}

Keywords: Time and cost overrun, construction industry, causative factors, Pakistan

\section{Introduction}

Poor performance of time and cost in construction industry is prominent issue since long time. This is global phenomenon. Morris (1990) studying 290 medium \& large on-going construction projects in the Public Sector with a cost of Rs. 20 crores or more reported that 186 had cost overruns with percentage cost overrun as much as $50 \%$. A study revealed that $70 \%$ of project in Saudi Arabia faced delay (Al-Khalil and Al-Ghafly, 1999) while in Qatar $80 \%$ of infrastructure projects experienced delay with $25 \%$ of additional time (Emam et al., 2015). Construction projects of Brazil face poor cost performance in investigation of 238 projects by where cost was exceeded by $82 \%$ (França and Haddad, 2018). Flyvbjerg et al. (2003) highlighted that performance of the construction projects has not improved over the time and its magnitude has not changed for the past 70 years. This problem of cost overrun is results of several factors and it is important to identify factors that contribute to cost overruns to avoid and minimize problems (Azhar et. al. 2008). Hence, it is very essential to study cost overrun problem in depth to avoid overrun and achieve successful projects. To avoid construction cost overrun, very first and most important step is to identify and understand the causative factors responsible for cost overrun (Memon et. al. 2011). Thus, this study has focused on identifying the factors of time and cost overrun. Focus of this paper is limited to construction works of Pakistan. 


\section{Literature Review}

Problem of time and cost overrun is emerging issue since long time. Over run of time and cost occurs due to several attributes which have been highlighted by several researchers from various parts of the world for long time. In order to study these problems, Baldwin and Manthei (1971) carried out a survey among the contractors, architects and engineers of United States to indicate the reasons of delays in construction projects. This survey helped in determining seventeen factors of delay among which design changes, subcontractors, sample approvals, jurisdictional disputes, financial matters were reported as top ranked factors. Later on studying Turkish construction industry, Arditi et. al. (1985) reported 23 attributes of delays where shortage of materials, delay of payment, contractor's difficulty to get credit purchase and organizational characteristics were found vital factors. A study of UK construction works carried out by Sullivan and Harris (1986) revealed that delay in information sharing and variability are key issues faced in construction works. Through administrating a survey among construction practitioners of Nigeria, Okpala and Aniekwu (1988) reported that shortage of materials, delay in payment and poor contractor management hinder the cost and time performance of construction works.

Later on, Mansifield et. al. (1994) talking about delay and cost overrun highlighted that mode of financing and payment of completed work as well as contract management are common reasons observed in construction works which affect the performance of the work. Frimpong (2003) through research of in construction works of Ghana confirmed that payment difficulties and poor contract management cause time and cost overrun. Lo et. al. (2006) emphasized that ground conditions and communication gaps among the stakeholders are serious issues which need to be improved to avoid project delays. Memon et. al. (2011) listed out 78 factors of cost overrun through reviewing the research works published the researchers throughout the world. Later on interviewing the experienced practitioners of working in public project of Malaysia, the authors pointed out that the project's cost performance is highly affected due to design related issues, contractor's experience and unrealistic time duration and requirements imposed by client. . .

Mahamid (2011) pointed out that construction projects often fail due to poor communication between the stakeholders involved in construction projects. The poor performance of public works resulting in cost increases and delivery times is frequently faced issue in developing countries. Alzara et. al. (2016) studied the performance of construction works of a university and spotlighted on the delay reasons. The authors mentioned that most critical issue which cause delay is the bidding system. Since, it is common practice that the lowest bid is selected for award and hence many low standard contractors reduce their rate to compete and win the project but later on this criterion becomes headache. These low bidding contractors do not have enough experience as well as resource availability which cause delay in completion of the works. In Afghanistan, corruption and payment issues are reported as major problems which affect the overall project cost (Niazi and Painting 2017) while in Zimbabwe progress payment and change orders are regarded as common causes of delay (Nyoni and Bonga 2017).

Maqsoom et al. (2018) highlighting the issues regarding time overrun in construction works of Pakistan mentioned that design and drawing related factors are major reason of failing the project completion on time. Besides that, performance of subcontractors and lack of availability of technical staff are also important causes which need serious attentions. Memon et. al. (2019) studied cost performance in construction works of Pakistan through questionnaire survey and found that all the stakeholders i.e. client, consultant and contractors agreed that common factors of cost overrun in construction works are lack of communication between parties, delay in obtaining the permits from governmental agencies, shortage of technical personnel (skilled labour), poor site management, lack of coordination between parties and poor financial control on site. Asiedu and Adaku (2019) pointed out that planning and scheduling play very important role in controlling the issue of cost overrun while ANDRIĆ et. al. (2019) argued that timely availability and performance of construction resources are very essential component in improving cost performance. Jadhav et. al. (2020) investigated 29 factors causing Cost Overruns in Satara city and collected 120 questionnaire forms amongst contractors, clients, quantity surveyors, project managers, engineers and architects working on building projects. Survey results showed that contractual claims, inadequate planning, additional work issues, delay in procuring and arrangement of construction equipment's, poor site management, fluctuation in the cost of building materials are the major factors for cost overrun in residential building construction projects.

\section{Research Method}

Data collection for this study was carried out through surveying the representatives of the contractors working on construction projects in Pakistan. Questionnaire form was prepared based on 55 common factors of time and cost overrun identified from review of published literature globally. Survey was carried out through emails, Google forms and in person visit of the construction sites. Data collection aimed to gather the perception of the practitioners regarding level of occurrence and severity level of the factors in causing time and cost overrun. The perception was recorded based on 5-poin likert scale. Scale adopted for measuring occurrence level was NO (Never Occur), RO (Rarely Occur), SO (Sometimes Occur), MO (Mostly Occur) and AO (Always Occur). The scale used for measuring significant level was NS (Not Significant), SS (Slightly Significant), MS (Moderately Significant), HS (Highly Significant) and ES (Extremely Significant). Gathered completed survey forms were analyzed statistically using MS Excel and SPSS 
software package. The factors were ranked based on Average Index (AI) values calculate using the formula adopted from Alhammadi and Memon (2020)

$$
A I=\frac{1 X_{1}+2 X_{2}+3 X_{3}+4 X_{4}+5 X_{5}}{X_{1}+X_{2}+X_{3}+X_{4}+X_{5}}
$$

Where,

$X_{I}=$ No of respondents for Never Occur/Not Significant

$X_{2}=$ No of respondents for Rarely Occur/Slightly Significant

$X_{3}=$ No of respondents for Sometimes Occur/Moderately Significant

$X_{4}=$ No of respondents for Mostly Occur/Very Significant

$X_{5}=$ No of respondents for Always Occur/Extremely Significant

\section{Results and Discussions}

A total of 46 representatives of the contractors responded in the survey against 100 personnel contacted. These respondents bear sound professional characteristics to provide required

In the process of data collection, a total of 33 respondents participated. These respondents were familiar with engineering knowledge and had sound experience in handling construction projects. Demographic details of the participants in shown in Table 1.

Table 1 - Characteristics of the respondents

\begin{tabular}{llcc}
\hline \multicolumn{1}{c}{ Category } & \multicolumn{1}{c}{ Items } & Frequency of respondents & Percentage of respondents \\
\hline Academic & Bachelor degree & 27 & $58.7 \%$ \\
& Diploma & 10 & $21.7 \%$ \\
& Masters & 8 & $17.4 \%$ \\
& PhD & 1 & $2.2 \%$ \\
\hline Working experience in & 5 to 10 years & 25 & $54.3 \%$ \\
construction industry & 11 to 15 years & 12 & $26.1 \%$ \\
& More than 15 years & 5 & $10.9 \%$ \\
& Less than 5 years & 4 & $8.7 \%$ \\
\hline Position in the & Engineer & 21 & $45.7 \%$ \\
construction company & Construction manager & 15 & $32.6 \%$ \\
& Quantity Surveyor & 4 & $8.7 \%$ \\
& Resident Engineer & 3 & $6.5 \%$ \\
& Planning Engineer & 2 & $4.3 \%$ \\
& Director & 1 & $2.2 \%$ \\
\hline Type of construction & Infrastructure & 21 & $45.7 \%$ \\
that you currently & Buildings & 21 & $45.7 \%$ \\
& Buildings and & 3 & $6.5 \%$ \\
\hline
\end{tabular}

From Table 1, it is indicated that all the major stakeholders involved in construction process were participating in this pilot study process. A significant number of participants with $39.4 \%$ represented contractors as contractors are key stakeholder in converting designed project into physical state. This is followed by consultant with $36.4 \%$ while there were $24.2 \%$ participants representing client organizations. These participants represented both public and private sector where $63.6 \%$ of the participants belong to private sector organization and $36.4 \%$ of the respondents are working in public/government sector projects. Among the participants $35.7 \%$ of the respondents have obtained engineering degree and $21.4 \%$ respondents have completed education up to post graduate level and remaining $28.6 \%$ of the respondents are diploma holders. These respondents are working in construction industry for several years. Statistical analysis reveals that $32.2 \%$ of the respondents have more than 10 years' experience of handling construction activities. A significant number of participants representing $48.5 \%$ are working as project engineers while $27.3 \%$ respondents are involved in management and $24.2 \%$ of the respondents are working as senior managers on project. The respondents have experience of handling infrastructure and building projects representing $90.9 \%$ of the participant while $9.1 \%$ of the 
respondents are engaged in management office in planning section. Perception of the respondents regarding relevancy of the factors with construction industry of UAE was analyzed with AI formula and the results are presented in Table 2.

Table 2 - Relevancy of factors causing cost overrun

\begin{tabular}{|c|c|c|c|c|c|c|c|c|c|}
\hline \multirow{2}{*}{ S. No } & \multirow{2}{*}{ Factors } & \multicolumn{8}{|c|}{ Level of Occurrence } \\
\hline & & NO & RO & SO & MO & AO & Total & AI & Rank \\
\hline 1 & $\begin{array}{l}\text { Delay in obtaining permits from } \\
\text { governmental agencies }\end{array}$ & 3 & 5 & 17 & 14 & 7 & 46 & 3.37 & 1 \\
\hline 2 & Financial difficulties faced by contractors & 3 & 9 & 12 & 15 & 7 & 46 & 3.30 & 2 \\
\hline 3 & Delay in Material procurement & 1 & 12 & 12 & 15 & 6 & 46 & 3.28 & 3 \\
\hline 4 & High cost of machinery and its maintenance & 6 & 6 & 13 & 11 & 10 & 46 & 3.28 & 3 \\
\hline 5 & Inaccuracy in cost estimation & 3 & 11 & 13 & 12 & 7 & 46 & 3.20 & 4 \\
\hline 6 & Delay in progress payment by owner & 3 & 10 & 17 & 9 & 7 & 46 & 3.15 & 5 \\
\hline 7 & Inadequate planning and scheduling & 6 & 9 & 9 & 16 & 6 & 46 & 3.15 & 5 \\
\hline 8 & Economic instability & 5 & 8 & 15 & 12 & 6 & 46 & 3.13 & 6 \\
\hline 9 & Mode of financing, bonds and payments & 4 & 12 & 11 & 13 & 6 & 46 & 3.11 & 7 \\
\hline 10 & Incompetency of subcontractors & 8 & 10 & 5 & 16 & 7 & 46 & 3.09 & 8 \\
\hline 11 & Financial difficulties of owner & 9 & 9 & 9 & 8 & 11 & 46 & 3.07 & 9 \\
\hline 12 & Bureaucracy in tendering method & 3 & 16 & 9 & 12 & 6 & 46 & 3.04 & 10 \\
\hline 13 & Slow decision-making by owners & 4 & 9 & 21 & 6 & 6 & 46 & 3.02 & 11 \\
\hline 14 & $\begin{array}{l}\text { Contractual claims, such as, extension of } \\
\text { time with cost claims }\end{array}$ & 6 & 9 & 16 & 8 & 7 & 46 & 3.02 & 11 \\
\hline 15 & Inaccurate Site investigation & 8 & 5 & 17 & 10 & 6 & 46 & 3.02 & 11 \\
\hline 16 & $\begin{array}{l}\text { Mistakes and discrepancies in contract } \\
\text { document }\end{array}$ & 6 & 10 & 13 & 12 & 5 & 46 & 3.00 & 12 \\
\hline 17 & Lack of modern Equipment & 11 & 7 & 7 & 15 & 6 & 46 & 2.96 & 13 \\
\hline 18 & Low productivity of labour & 9 & 7 & 16 & 6 & 8 & 46 & 2.93 & 14 \\
\hline 19 & Schedule Delay & 10 & 7 & 12 & 10 & 7 & 46 & 2.93 & 14 \\
\hline 20 & Lack of experience of contractor & 8 & 11 & 12 & 7 & 8 & 46 & 2.91 & 15 \\
\hline 21 & Lack of constructability & 5 & 17 & 7 & 11 & 6 & 46 & 2.91 & 15 \\
\hline 22 & $\begin{array}{l}\text { Shortage of technical personnel (skilled } \\
\text { labour) }\end{array}$ & 9 & 11 & 9 & 10 & 7 & 46 & 2.89 & 16 \\
\hline 23 & $\begin{array}{l}\text { Relationship between management and } \\
\text { labour }\end{array}$ & 3 & 18 & 12 & 7 & 6 & 46 & 2.89 & 16 \\
\hline 24 & $\begin{array}{l}\text { Delay in inspection and approval of } \\
\text { completed works by consultant }\end{array}$ & 6 & 11 & 16 & 8 & 5 & 46 & 2.89 & 16 \\
\hline 25 & Poor project management on site & 9 & 6 & 17 & 9 & 5 & 46 & 2.89 & 16 \\
\hline 26 & Poor financial control on site & 5 & 11 & 17 & 10 & 3 & 46 & 2.89 & 16 \\
\hline 27 & Inadequate monitoring and control & 7 & 10 & 17 & 6 & 6 & 46 & 2.87 & 17 \\
\hline 28 & Fraudulent practices and kickbacks & 10 & 8 & 12 & 10 & 6 & 46 & 2.87 & 17 \\
\hline 29 & Shortage of labour on site & 6 & 15 & 11 & 8 & 6 & 46 & 2.85 & 18 \\
\hline 30 & Delay payment to supplier /subcontractor & 7 & 12 & 12 & 11 & 4 & 46 & 2.85 & 18 \\
\hline 31 & Unforeseen ground condition & 8 & 12 & 14 & 3 & 9 & 46 & 2.85 & 18 \\
\hline 32 & Fluctuation of prices of materials on site & 4 & 18 & 9 & 12 & 3 & 46 & 2.83 & 19 \\
\hline 33 & Mistakes during execution of works & 6 & 10 & 19 & 8 & 3 & 46 & 2.83 & 19 \\
\hline 34 & $\begin{array}{l}\text { Inappropriate overall organizational } \\
\text { structure }\end{array}$ & 6 & 11 & 18 & 7 & 4 & 46 & 2.83 & 19 \\
\hline 35 & Poor Supervision on site & 8 & 12 & 14 & 5 & 7 & 46 & 2.80 & 20 \\
\hline
\end{tabular}




\begin{tabular}{llcccccccc}
\hline 36 & Lack of communication between parties & 5 & 12 & 19 & 7 & 3 & 46 & 2.80 & 20 \\
37 & Late delivery of materials on site & 3 & 11 & 26 & 5 & 1 & 46 & 2.78 & 21 \\
38 & Problem with neighbours & 9 & 9 & 15 & 10 & 3 & 46 & 2.76 & 22 \\
39 & Poor Quality of materials & 8 & 10 & 18 & 6 & 4 & 46 & 2.74 & 23 \\
40 & Mistakes and Errors in design & 9 & 11 & 12 & 11 & 3 & 46 & 2.74 & 23 \\
41 & Unsuitable construction methods & 14 & 6 & 12 & 6 & 8 & 46 & 2.74 & 23 \\
42 & Poor Contract management & 6 & 14 & 16 & 6 & 4 & 46 & 2.74 & 23 \\
43 & Delay in Design & 7 & 14 & 13 & 9 & 3 & 46 & 2.72 & 24 \\
44 & Lack of coordination between parties & 3 & 18 & 17 & 5 & 3 & 46 & 2.72 & 24 \\
45 & Poor site management & 10 & 9 & 14 & 11 & 2 & 46 & 2.70 & 25 \\
46 & Unnecessary interface by owner & 12 & 13 & 8 & 5 & 8 & 46 & 2.65 & 26 \\
47 & Slow information flow between parties & 7 & 14 & 13 & 12 & 0 & 46 & 2.65 & 26 \\
48 & Waste on site & 13 & 4 & 19 & 7 & 3 & 46 & 2.63 & 27 \\
49 & Shortages of materials & 9 & 13 & 17 & 4 & 3 & 46 & 2.54 & 28 \\
50 & Complicated design & 15 & 7 & 14 & 4 & 6 & 46 & 2.54 & 28 \\
51 & Change in the scope of the project & 7 & 22 & 7 & 7 & 3 & 46 & 2.50 & 29 \\
52 & Unrealistic contract duration imposed & 12 & 14 & 11 & 5 & 4 & 46 & 2.46 & 30 \\
53 & Frequent changes in design & 10 & 19 & 7 & 7 & 3 & 46 & 2.43 & 31 \\
54 & Number of projects going on at same time & 15 & 8 & 14 & 6 & 3 & 46 & 2.43 & 31 \\
55 & Policy of lowest cost bidding policy & 13 & 14 & 14 & 2 & 3 & 46 & 2.30 & 32 \\
\hline
\end{tabular}

From table 2, it can be reported that 16 of 55 factors have AI value more than 3 which means these 16 factors can be regarded as Medium Occurring in construction works. Among these factors, delay in occurring permits from governmental agencies is reported as top ranked factor. This factor has major influence in infrastructural work as compared to building works such as in road works, there are many hurdles faced which need permission from governmental agencies. For example if road is crossing through railway track or these are certain utility service in the way of road, then governmental permission are required to cross through railway track or relocate the underground utilities. "Financial difficulties faced by the contractors" is reported as $2^{\text {nd }}$ ranked factors occurring in construction projects. Results indicate that delay in material procurement and high cost of machinery is placed at $3^{\text {rd }}$ rank by the practitioners which occur in construction projects followed by inaccuracy in cost estimation. Some of the practitioners mentioned that in construction mostly incomplete drawings are provided for tendering process and estimation is also prepared based on those drawings while after completion of bidding process, the contractors are issued working drawing which are slightly different that tender drawings. This affects the estimate of the project and cause cost overrun. This study also assessed effect of these factors on time and cost based on average index value calculated for each factors as presented in table 3.

Table 3 - Effect of the Factors on Time and Cost Overrun

\begin{tabular}{clcccc}
\hline \multirow{2}{*}{ S. No } & \multicolumn{1}{c}{ Factors } & \multicolumn{2}{c}{ Effect on Time Overrun } & \multicolumn{2}{c}{ Effect on Cost Overrun } \\
\cline { 3 - 6 } & & AI & Rank & AI & Rank \\
\hline 1 & High cost of machinery and its & 3.59 & 1 & 3.37 & 1 \\
2 & maintenance & 3.43 & 2 & 3.20 & 3 \\
3 & Inadequate planning and scheduling & 3.39 & 3 & 2.89 & 9 \\
4 & Slow information flow between parties & 3.33 & 4 & 3.11 & 5 \\
5 & Delay in progress payment by owner & 3.28 & 5 & 2.72 & 13 \\
6 & Incompetency of subcontractors & 3.26 & 6 & 3.26 & 2 \\
7 & Inaccuracy in cost estimation & 3.24 & 6 & 3.00 & 7 \\
8 & Schedule Delay & 3.22 & 7 & 2.70 & 13 \\
& Delay in obtaining permits from & & & & \\
\hline
\end{tabular}




\begin{tabular}{|c|c|c|c|c|c|}
\hline 9 & Delay in Material procurement & 3.22 & 7 & 3.17 & 4 \\
\hline 10 & Fraudulent practices and kickbacks & 3.22 & 7 & 2.72 & 13 \\
\hline 11 & Poor site management & 3.22 & 7 & 3.02 & 7 \\
\hline 12 & Poor project management on site & 3.20 & 7 & 2.78 & 11 \\
\hline 13 & Mistakes during execution of works & 3.17 & 8 & 2.98 & 7 \\
\hline 14 & $\begin{array}{l}\text { Contractual claims, such as, extension of } \\
\text { time with cost claims }\end{array}$ & 3.11 & 9 & 2.87 & 10 \\
\hline 15 & Inaccurate Site investigation & 3.11 & 9 & 3.02 & 7 \\
\hline 16 & $\begin{array}{l}\text { Relationship between management and } \\
\text { labour }\end{array}$ & 3.11 & 9 & 2.93 & 8 \\
\hline 17 & $\begin{array}{l}\text { Delay in inspection and approval of } \\
\text { completed works by consultant }\end{array}$ & 3.11 & 9 & 2.91 & 9 \\
\hline 18 & Delay payment to supplier /subcontractor & 3.11 & 9 & 2.91 & 9 \\
\hline 19 & Financial difficulties of owner & 3.09 & 9 & 3.00 & 7 \\
\hline 20 & $\begin{array}{l}\text { Mistakes and discrepancies in contract } \\
\text { document }\end{array}$ & 3.09 & 9 & 2.98 & 7 \\
\hline 21 & Unforeseen ground condition & 3.09 & 9 & 2.96 & 8 \\
\hline 22 & Shortage of labour on site & 3.07 & 10 & 2.96 & 8 \\
\hline 23 & Financial difficulties faced by contractors & 3.04 & 10 & 3.00 & 7 \\
\hline 24 & Inadequate monitoring and control & 3.04 & 10 & 3.09 & 5 \\
\hline 25 & Delay in Design & 3.04 & 10 & 2.89 & 9 \\
\hline 26 & Economic instability & 3.02 & 11 & 3.33 & 1 \\
\hline 27 & Slow decision-making by owners & 3.02 & 11 & 2.85 & 10 \\
\hline 28 & Lack of constructability & 3.02 & 11 & 2.91 & 9 \\
\hline 29 & Mistakes and Errors in design & 3.02 & 11 & 2.93 & 8 \\
\hline 30 & Poor Supervision on site & 3.00 & 11 & 3.00 & 7 \\
\hline 31 & Lack of coordination between parties & 3.00 & 11 & 2.85 & 10 \\
\hline 32 & Low productivity of labour & 2.98 & 11 & 2.83 & 10 \\
\hline 33 & Waste on site & 2.96 & 12 & 2.98 & 7 \\
\hline 34 & $\begin{array}{l}\text { Shortage of technical personnel (skilled } \\
\text { labour) }\end{array}$ & 2.93 & 12 & 2.85 & 10 \\
\hline 35 & Poor financial control on site & 2.93 & 12 & 3.02 & 7 \\
\hline 36 & Mode of financing, bonds and payments & 2.91 & 13 & 3.20 & 3 \\
\hline 37 & Bureaucracy in tendering method & 2.89 & 13 & 2.83 & 10 \\
\hline 38 & Lack of modern Equipment & 2.89 & 13 & 2.89 & 9 \\
\hline 39 & Lack of experience of contractor & 2.89 & 13 & 3.20 & 3 \\
\hline 40 & Frequent changes in design & 2.89 & 13 & 3.22 & 3 \\
\hline 41 & Late delivery of materials on site & 2.87 & 14 & 3.07 & 6 \\
\hline 42 & Poor Contract management & 2.87 & 14 & 2.80 & 11 \\
\hline 43 & Problem with neighbours & 2.85 & 14 & 2.76 & 12 \\
\hline 44 & Complicated design & 2.85 & 14 & 2.83 & 10 \\
\hline 45 & Policy of lowest cost bidding policy & 2.85 & 14 & 2.63 & 14 \\
\hline 46 & $\begin{array}{l}\text { Inappropriate overall organizational } \\
\text { structure }\end{array}$ & 2.83 & 14 & 3.15 & 4 \\
\hline 47 & Unsuitable construction methods & 2.83 & 14 & 3.24 & 2 \\
\hline 48 & Lack of communication between parties & 2.80 & 15 & 2.96 & 8 \\
\hline
\end{tabular}




\begin{tabular}{|c|c|c|c|c|c|}
\hline 49 & Shortages of materials & 2.80 & 15 & 2.70 & 13 \\
\hline 50 & Fluctuation of prices of materials on site & 2.78 & 15 & 3.13 & 4 \\
\hline 51 & Change in the scope of the project & 2.78 & 15 & 2.87 & 10 \\
\hline 52 & Unrealistic contract duration imposed & 2.78 & 15 & 3.02 & 7 \\
\hline 53 & Poor Quality of materials & 2.72 & 16 & 2.85 & 10 \\
\hline 54 & Number of projects going on at same time & 2.72 & 16 & 2.72 & 13 \\
\hline 55 & Unnecessary interface by owner & 2.67 & 17 & 2.96 & 8 \\
\hline
\end{tabular}

Ranking of the factors presented in table 3 indicate that high cost of machinery and its maintenance is reported as the most significant factors in causing time and cost overrun in construction projects of Pakistan. Inadequate planning and scheduling is reported as $2^{\text {nd }}$ ranked significant factors in causing time overrun while it is ranked at $3^{\text {rd }}$ place in causing cost overrun. Respondents highlighted that in causing cost overrun run, second ranked significant factors is adoption of unsuitable construction method. Slow information flow between parties is reported as $3^{\text {rd }}$ ranked factor in causing time overrun while it has slightly lower effect in causing cost overrun and the respondents placed this factors at rank 9. In causing cost overrun, $3^{\text {rd }}$ ranked factors as perceived from the respondents is mode of financing, bonds and payments. The practitioners mentioned that delay in progress payment by owner is $4^{\text {th }}$ significant factor in causing time overrun while the respondents placed this factor at $5^{\text {th }}$ place in causing cost overrun. On the contrary, fluctuation of prices of materials on site is reported as $4^{\text {th }}$ significant factor in causing cost overrun. This is very serious factor and the fluctuation in material prices has become headache for the owners and sponsoring agencies. Incompetency of subcontractors is the 5th significant factors causing time overrun however this is $13^{\text {th }}$ ranked factor in causing cost overrun.

\section{Conclusion}

This paper studied the factors responsible for time and cost overrun in construction projects of Pakistan. Review of similar studies carried out in past globally resulted in listing out 55 common factors which were investigated through questionnaire survey. Gathered data was analysed with average index method to rank the factors. From analysis, it was found that delay in obtaining permits from governmental agencies, financial difficulties faced by contractors, delay in material procurement, high cost of machinery \& its maintenance and inaccuracy in cost estimation are the five most commonly faced factors. Study also addressed the assessment of significance level of the factors in causing time and cost overrun. It was found that high cost of machinery and its maintenance; inadequate planning and scheduling, slow information flow between parties, delay in progress payment by owner and incompetency of subcontractors are the top five factors which cause time overrun while high cost of machinery \& its maintenance; unsuitable construction methods, lack of experience of contractor, fluctuation of prices of material on site and inadequate monitoring $\&$ control are top five factors which cause cost overrun in construction projects of Pakistan. These finding will be helpful for the practitioners in planning properly to control the problem of time and cost overrun.

\section{Acknowledgement}

The authors would like to thank Quaid-e-Awam University of Engineering, Sciences and Technology, Nawabshah, Sindh, Pakistan for supporting this study. Also we are thankful to construction practitioners for providing comprehensive and important information and a lot of cooperation which made data collection easier.

\section{References}

Alhammadi, A. S. A. M., and Memon, A. H. (2020), "Ranking of the Factors Causing Cost Overrun in Infrastructural Projects of UAE", International Journal of Sustainable Construction Engineering and Technology, Vol. 11, No. 2, pp. 204-211

Al-Khalil, M. I., \& Al-Ghafly, M. A. (1999), "Important causes of delay in public utility projects in Saudi Arabia", Construction Management \& Economics, Vol. 17, No. 5, pp. 647-655

Alzara, M., Kashiwagi, J., Kashiwagi, D. and Al-Tassan, A. (2016), "Important Causes of Delayed Projects in Saudi Arabia vs. PIPS: A University Campus Case Study," CIBW117.com/journal C PBSR

Andrić, J. M., Mahamadu, A. M, Wang, J., Zou, P. X. W and Zhong, R (2019), "The cost performance and causes of overruns in infrastructure development projects in Asia”, Journal of Civil Engineering and Management, Vol. 25, No. 3, pp. 203-214 https://doi.org/10.3846/jcem.2019.8646 
Arditi, D., Akan, G.T. and Gurdamar, S. (1985), "Reasons for delays in public projects in Turkey", Construction Management and Economics, Vol. 3, pp. 171-181

Asiedu, R. O and Adaku, E (2019), "Cost overruns of public sector construction projects: A developing country perspective", International Journal of Managing Projects in Business

Azhar, N., Farooqui, R. U., and Ahmed, S. M. (2008). Cost Overrun Factors In Construction Industry of Pakistan. Paper presented at the First International Conference on Construction in Developing Countries (ICCIDC-I), held in 2008 at NED University Karachi, Pakistan

Baldwin, J. R., Manthei, J. M., Rothbart, H., and Harris, R. B. (1971), "Causes of delay in the construction industry", Journal of the Construction Division, Vol. 97, No. 2, pp. 177-187

Emam, H., Farrell, P., and Abdelaal, M. (2015, September). Causes of delay on infrastructure projects in Qatar. In Proceedings of the 31st Annual ARCOM Conference, Lincoln, UK, Association of Researchers in Construction Management, Nottingham, UK (pp. 773-782)

Flyvbjerg, B., Holm, M. K. S and Buhl, S. L (2003), "How common and how large are cost overruns in transport infrastructure projects?", Transport Reviews, Vol. 23, No. 1, 71-88

França, A., and Haddad, A. N. (2018), “Causes of Construction Projects Cost Overrun in Brazil”, International Journal of Sustainable Construction Engineering and Technology, Vol. 9, No. 1, pp. 69-83

Frimpong, Y., Oluwoye, J., \& Crawford, L. (2003), "Causes of delay and cost overruns in construction of groundwater projects in a developing countries; Ghana as a case study", International Journal of Project Management, Vol. 21, pp. $321-326$

Jadhav, D., Konnur, B. A. and Patil, S. (2020), "Analysis of factors causing cost overruns in residential building construction projects", International Journal of research in engineering, science and management, Vol. 3, No.7

Lo, T. Y., Fung, I. W., \& Tung, K. C. (2006), “Construction delays in Hong Kong civil engineering projects”, Journal of construction engineering and management, Vol. 132, No. 6, pp. 636-649

Mahamid, I. (2011), "Risk matrix for factors affecting time delay in construction projects; owner's perspective", Engineering, Construction and Architectural Management, Vol. 18 No. 6, pp. 609-617

Mansfield N. R, Ugwu O. O and Doran T. (1994), "Causes of delay and cost overruns in Nigerian construction projects", Vol. 12, No. 4, pp. 254-260

Maqsoom, A., Khan, M. U., Khan, M. T., Khan, S, Ullah, N. and Ullah, F. (2018), "Factors Influencing the Construction Time and Cost Overrun in Projects: Empirical Evidence from Pakistani ConstructionIndustry", Proceedings of the $21^{\text {st }}$ International Symposium on Advancement of Construction Management and Real Estate

Memon, A. H., Rehman, I. A. and Azis, A. A. A. (2011), "Preliminary Study on Causative Factors Leading to Construction Cost Overrun”, International Journal of Sustainable Construction Engineering \& Technology, Vol 2, No. 1

Memon, A. Q., Memon, A. H, Soomro, M. A. and Rahman, I. A. (2019), “Common Factors Affecting Time and Cost Performance of Construction Projects in Pakistan”, In Pakistan Journal of Science, Special Issue, September 2019

Morris (1990) Cost and Time Overruns in Public Sector Projects, in Economic and Political Weekly, Nov.24, 1990, Vol. XXV, No.47, pp.M-154 to M-168

Niazi, G. A and Painting, N (2017), "Significant factors causing cost overruns in the construction industry in Afghanistan”, Procedia Engineering, Vol. 182, pp. 510-517

Nyoni, T., Bonga, W. G. (2017), “Towards Factors Affecting Delays in Construction Projects: A Case of Zimbabwe”, Dynamic Research Journalof Economics and Finance (DRJ-JEF), Vol. 35, No. 1, pp. 12-28 
Okpala, D. C., and Aniekwu, A. N. (1988), "Causes of high costs of construction in Nigeria”, Journal of Construction Engineering and Management Accounting Research, Vol. 114, No. 2, 233-244

Sullivan, A., and Harris, F. C. (1986), “Delays on large construction projects. International”, Journal of operations \& production management 